\title{
Sample Transcriptions of Performance Texts
}

(Page numbers are those on which verses appear in text)

\section{Chapter 2: Bhojalī}

Page 30: devī gangā devī gangā

lahar turangā ho

tumhar lahar bhojalī

bhīje ātḥo angā

Page 3 I: kahă ke to khātu māṭ̂̄

kahâ ke to canighoriyā

kahă ke to canghoriyā

bhojalī jamoiyā

hă ho devī gañgā . . .

raygarḥ ke to khātu māṭ̂̄

candarpur canghoriyā

candarpur canghoriyā

phuljhar ke to pilì bāī

bhojalī jamoiyā

hã ho devī gañgā...

kahâ ke khātu māṭī

kahă ke ṭuknī

kahã ke țuknī

cūhaya motī pānī

hă ho devī gangā ...

kumhār ghar ke khātu māṭ̂̄

karrā ghar ke ṭuknī

karrā ghar ke țuknī 
rājā ghar ke javā bhojalī

cūhaya motī pānī

hã ho devī gañgā . . .

Page 32: (without all the repetitions provided in the translation)

dḥimika dḥimi mor bājan ba jāī o dḥimika dḥimi

mor bājan bajāī o kahă ke bājan

āy rāhilā o kahă ke bājan

telin kalārin dāī bhojalī ujhānay o telin kalārin

dāī bhojalī ujhānay o jihã ke bājan

ày rāhilā o jihắ ke bājan

Page 33: līpī dāren potī dāren

chārī paren konhā ho

chārī paren konhā ho

hamre bhojalī dāī ke dekhat rabo conhā

hă ho devī gañā ...

Page 34: acarī tariyā gayen

pacharī pițāyen ho

pacharī pițāyen ho

ajab gajab tariyā ke pār bhojalī paloyen

hă ho devī gañgā. . .

Page 38: jal binā machlī

pavan binā dhān

pavan binā dhān

sevā binā bhojalī

ke tarasthay parān

hă ho devī gañgā ...

Page 38: mấdī bhar jondharī

poris kuśiyare

poris kuśiyare

jaldī jaldī barhhā

bhojalī huśiyāre

hă ho devī gangā . . .

Page 39: ā̄î gaīs pūrā bohāī gaīs kacrā

hamro bhojalī dāī ke sone sone añcarā

àī gaīs pūrā bohāī gaīs malgī

hamro bhojalī dāì ke sone sone kalgī

Page 39: dūdh mañgen pūt mañgen 
au mañgen āsiśs

au mañgen āśîs

thāre hai kosilyā

devathay āsisśs

hã ho devī gañgā . . .

Page 4I: kaunav ceghe hāthiyā

kaunav ceghe ghoṛvā kaunav ceghe ghorvā kaunav ceghe pālukī kaunav ceghe ḍolvā hă ho devī gañgā . . .

rājā ceghe hāthiyā devānā ceghe ghợvā devānā ceghe ghoṛā rānī ceghe pālukī bhojalī ceghe ḍolvā hã ho devī gañgā . . . kaun gã ke kārī tūrī kaun gã ke sagāvā ho kaun gã ke sagāvā ho jabhe ānbe nādhik nādhī tabhe ceghav dolvā hã ho devī gañgā . . .

Page 4I: tulsī ke caũrā mukut bhaige ānganā mukut bhaige ānganā phire phire bāmhan devtā bharī ha lagānā hâ ho devī gañgā . . .

Page 42: ghīr ghīr motar āye bhītar lage tālā bhītar lage tālā jarrā gâ ke tūrāman lā lege pulīs wālā hẫ ho devī gañgā . . .

kahâ ke to dār cāur kahâ ke to bañganiyā kahã ke to bañganiyā kahã ke to dīṛva chokrā 
bulthe manjjhiniyā

hâ ho devī gangā . . .

narsingpur ke dār cāur

jagdīspur ke baṅganiyā

jagdīśpur ke bangganiyā

jarrā ke dịrva chokrā

bulthe manjjhiniyā

hă ho devī gangā . . .

Page 43: jhan jhan murdang bājā

bāje bāje kartāle

bāje bāje kartāle

hamar ghar ke mālik nāithe

lebo parsāde

hă ho devī gañgā . . .

Page 44: bấse ke tḥợā me bharī daren cāur bharī daren cāur kahar mahar karte bhojalī dāī ke rāhū hă ho devī gangā ...

bâse ke tḥorā me rañga coṭi dāì ke rañga coṭi dāì ke māthe he rangoiyā bhojalī bonā dāī ke hă ho devī gañgā ...

Page 45: thārī nā ākā cāur gārḥulā me dūdh gārḥulā me dūdh thạāe hai kauśalya bāī mānigthe putra hă ho devī gañgā...

\section{Chapter 3: Dālkhāì}

Page 53: $\quad$ ki ḍālkhāī re māgh re mādhav āsibe balī sej sajāṛī hī pākhựā malī 
mānikyar dīp jālī basīchī

cakśu ujāgare dūtī lo

pāhī galā nìtī chārịi de bāțh

nandar cāṭ rāhī kesarī nāī pāre bhūlī

ki ḍālkhāī re

ki ḍālkhāī re

phāgun mās re phāgu durlabh

phāgu khelu thībe rādhā mādhabh

phāgu kuṇḍare karpur mesāi

phāgu khelu thībe ilī lo

jādhu gosāĩ chāṛī de bāṭh

ki ḍālkhāī re

\section{Chapter 4: Sūa Nāc}

Page 82: tore ghar ke muhutī kaise samāū nīe tore ghar ke ho re tore ghar ke muhutī

Page 83: [without verse repetitions] jaise o maiyā tum liho aur diho re suānā ho jaise mẽ liho re âsisiś anne aur dhanne tor ghar bharīa re suānā jiho maiyā lākho vārî́s bālak bețā bīhā karī lāne re suānā ho korā me nātī khelā

Page 84: baṛe ghar baṛe ghar kahă te àe e suānā baṛe o ghar die man țare jogī bairāgī sabo din sabo din e suānā hamu diā bachar din

Page 85: rise ke mare bhītar paśí jāe e suānā herio āno sūpā bharī dhān

Page 86: kahar kahar kare mor kārī koilī re e suānā ho mirīgā bole re ādhī rāt e nind soiche mor gãõ ke gauṇtiyā e suānā jekar bahinī gae pardeś ...

Page 92: jao jao suā andanban candanban re suānā țorī āno āmā ghāū 
kāhe rengī jāiho āū kāhe ựiho re suānā ho kāhe me lānī ho ho ṭor pavo reñgī jāibe pakurī ựī āibe re suānā ho cõce mẽ ānī ho ho tọ āne bar ānihõ mãi āmā ghaūlā re suānā ho kone lā dihõ re dharāy bārah bachar ke candanmatī thargịi re suānā johī lā suā debe re dharāy

Page 99: chāṭi tor phātige re âkhī tor phūṭige re suānā wahī de tor bahinī ke ghar

Page 99: hârị dhovat dhovat bhauj̄̄ dekhat he re suānā līgirrā lagāy ke nandan har

Page ıoo: bhāī lā dehẽ rañg mahalā dumhalā re suānā ham lā tai dehẽ videś

\section{Initial Verses of "The Song of Subanbali"}

ramo ramo śri horī rāmo je

ramo ramo śri horī rāmo

garūrḥ la bāhan gu rāmo

kauśalyā nandan

banu acche sarlā debī me

banu acche manglā moro

prasanna hoibe sarlā

prasanna hoibe

ādī kandar gữ̄ì ānī mũi

kapīl sarg ānī

śibankar bāhunī re sarla

śibankar bāhunī

ete bele suban baile

ete bele suban baile

kurḥī kẫcī dharī karī

hāthe țupulī dhārī

khel ghar gale re suban

khel ghar gale 
e khel gharẽ khel khelile

khel gharẽ khel khelile

rājestī je māne re

mor bambāī śahar

kațak rāj ra bambāī

mor kațak śahar

kāl paṛi thîle rājestī

tumba gārị thīle

rūndha moro re randhāī karī

mor khāī karī mor pī karī

sej ka palang karī re moro

rājestī je pua

dasāī suile go se māne

dasāī suile

ete bele bandhiyā rājā re

eṛe duṣtḥ māno

\section{Kathānī Kühā: Initial Lines after the Vandanā}

P. guțe steśan te thīlā. guțe steśan te thỉlā. āū seī sțeśan thî moțor sena kãr haūche? ki ā ... senu jamā haūche ār senu pher dūsar dūsar dig ke moțar cālū hoūche. je stéśan thī lok utī̄san aur kâr karasan?

A. ipāk sepāk jāisan.

P. je sțeśan thî lok ut̄îrsan aur kấr karasan?

A. caghsan ghale.

P. neî? duhī ța hesī, hế? utī̄san aur caghsan ghale. je sena caghā utrā hesī sṭeśan thî àū kichī neīna agbār bhajiyă ai.

je sena kắr haūche? purub digũ ghale gārīi ailā ār paścim digũ ghale gārī āilā. āū se sțeśan thî duhẽkar gārị kâr helā?

A. thāạ helā.

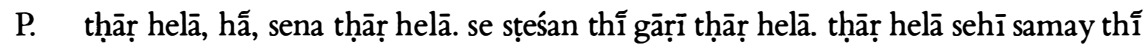
je se gāṛī lok ghale utīrle ārī gārịi lok ghale utīrle. neī?

A. hă.

P. kineīutrí?

A. utīrle.

P. utīrle. acchā, duhī gãrī lok utīrle. je senu se duhī gārị jane jane duī lok jāikarí kấr kale je? guṭe chāī tale basle. duhī lūka guṭe chāī tale basle, āū se chāī tale basbā mātar ke jane bailā, "bhāī, muĩ bahut dhurīyathũ āsuchẽ lekin mor na kāṛi thîlā sarī galā bīṛi țāa ache," bailā. 

bailā.

"je bhāī, muî nuâ kāṛī ghinī thīlế mor bīṛī sarī galā na, mor na kārī ache,"

duhī luka bịnị āū kāṛībāhar kale, sena pīle aur sena se paricay nīā nūī hele. duhījan se bīrị kāṛī kale tārpare se mane kắr kārīchan? je paricay nīā nūīi hele. paricay mane?

A. cīn pahcān.

P. tuĩ kenar aū? tuĩ kâhī jaūchū? itā paricay heūche. ta senu duhī lukar paricay heūchan.

Ṣong: tāre tāre tāre tāre re tāre tā tāre re re nāre nāre re.

keũ deśú tuĩ ta āsīachū?

keũ deśú tui ta āsīachū?

sțeśane rahichū re bhāī.

kāhĩ ke jāūchū?

tor paricay detū ke bābū, paricay detū.

purubaru muí āsūache.

paścim ku re jāūche.

muĩ kām kâ sīkhīchẽ je bhāī;

dām ka neūche.

deś deś kãi būlūche re muĩ ta.

kām kãi karu.

keũ dĩgru tuî âsīachū?

kāhir lāgī mote puchūchū?

keũ deś ke ta j̄ibū re tuí ta?

nagra ke ta jübū?

mẫ nāī mor gaõ nāī.

bāpo nāī mor thābo nāī.

muí jỉbī kito kāhî je bhāī

jỉbī kito kāhí?

muî ta kām re sīkhīchẽ

deś deś kãi būlua.

muî thịkā kãi naūche je bhāī.

tḥīkā kãi naū. 